\title{
Reconnecting Language and Materiality in Christian Reading: A Comparative Analysis of Two Groups of Protestant Women
}

\author{
BRITT HALVORSON \\ Anthropology, Colby College, Waterville, ME, USA
}

\author{
INGIE HOVLAND \\ Department of Religion, University of Georgia, Athens, GA, USA
}

\section{INTR ODUCTION}

In the last four decades, ethnographic studies of reading have challenged the idea that reading is a straightforward activity of taking knowledge from texts. Beginning with the foundational volume The Ethnography of Reading (J. Boyarin 1993a), scholars have traced the shifting interrelationships of texts, readers, and acts of knowledge-making as written works are accommodated to different culturally located reading situations. This work has shown that anthropological questions can be asked about how written texts are dynamically interwoven with the spaces and relations in which they are read (Rosen 2015; Reed 2018). In doing so, ethnographic studies have drawn attention to and amply disputed one prevailing cultural ideology of reading: the notion that reading is a uniform, unmediated or functional practice of drawing out the meaning of a set of fixed words on the page.

Yet, other cultural ideologies of reading have gone largely unaddressed in the literature. In this article, we explore one of these problems by studying comparatively across two sites how reading is embodied or, in other words,

Acknowledgments: We wish to thank the CSSH editors and anonymous reviewers for insightful and constructive readings of our manuscript. Britt Halvorson is grateful for guidance from the ECLA archivist Paul Daniels and his staff, and research support from the Alfred P. Sloan Foundation and the University of Michigan's Department of Anthropology. 
what relationship emerges between bodies and texts in the act of reading. Recent work has sometimes framed the relative lack of emphasis on the embodied dimensions of reading as an argument for attending to the practice rather than the content of reading (Rosen 2015). Here, we instead aim to develop an approach that explores the mutually reinforcing dimensions of textual interpretation and embodied practice. This effort to theorize embodied reading grows out of our archival research projects on two groups of Protestant women: one in 1920s Norway (Hovland) and the other in the 1950s United States (Halvorson). We grew aware that, just as we were engaging in a situated practice of archival reading that involved our own cisgender female, white middle-class identities and political-economic relations in academia, so too were Protestant women in these two settings relating readings complexly to their embodied experiences.

Though religious groups have been the focus of a substantial number of the existing ethnographies of reading (e.g., J. Boyarin 1993b; Keller 2005; Engelke 2007, 2013; Bielo 2009a; 2009b), engagement with what Elizabeth Long (1993) calls "trivial" readings in ordinary places, rather than higher-status exegesis of sacred texts in spaces of worship and formal instruction, have been less common (but see Griffith 2004). We will explore what can be gained by comparatively analyzing the embodiment of reading in lower-status Protestant reading activities critical to the reproduction of Christian bourgeois ideals of gender and race: that of early and mid-century white Protestant women in the West, yet on the edge of imperial projects overseas, reading female-authored, lowstatus magazine articles, commentaries, and advice columns. We propose that reading is a comparative endeavor not only for us but also for the Protestant women who are our focus, as they repeatedly relate, link, and distinguish the material conditions of their reading and the stories that capture their attention. Relating to exemplary figures in written texts was a crucial element of this cultural process, as it enabled women in both communities to try out and identify with specific, embodied moral paths of piety.

When we compared notes across our archival work in 1920s Norway and the 1950s United States, one biblical story emerged as an important orienting framework through which women in these two Protestant communities negotiated their embodied identities. This was the story of Mary and Martha of Bethany from the Gospel of Luke 10:38-42:

38 Now it came to pass, as they went, that [Jesus] entered into a certain village: and a certain woman named Martha received him into her house.

39 And she had a sister called Mary, which also sat at Jesus' feet, and heard his word.

40 But Martha was cumbered about much serving, and came to him, and said, Lord, dost thou not care that my sister hath left me to serve alone? bid her therefore that she help me. 
41 And Jesus answered and said unto her, Martha, Martha, thou art careful and troubled about many things:

42 But one thing is needful: and Mary hath chosen that good part, which shall not be taken away from her. ${ }^{1}$

Indeed, although archival materials are our primary focus here, it is interesting to note at the outset that the biblical story has had a multifaceted, enduring social life in one of these two Protestant communities. While Halvorson was doing field research in 2004-2006 in a Minnesotan Lutheran medical aid organization, one long-term white volunteer and former missionary to Madagascar from 1952 to 1982, Lois, sang in an all-women's choir in her St. Paul Evangelical Lutheran Church in America (ELCA) congregation that was called the "Marys and Marthas." When she mentioned to several of her fellow volunteers that she had choir practice one evening, she joked self-effacingly that she was "just a Martha." However, Lois's interpretation of the biblical text was not nearly as clear-cut as it initially appeared. When I (Halvorson) asked her later that same afternoon about the story of Mary and Martha, Lois said that she saw Martha as a figure equally important to Mary, but not one who readily gravitated toward quiet study, something she could relate to herself. Martha's work serving others was significant, Lois noted, but had to be paired with a "continual dedication of the work to Christ."

Similarly, as I was reading Women's Missionary Federation materials in a local archive of the ELCA in St. Paul, Mary and Martha appeared again and again. One day, while taking a break from my reading and having coffee with the archival assistants around the central meeting table, I fell into conversation with a Lutheran woman seminarian. The seminarian told me that while Mary presents a significant scholarly example for Christian women, some suggest the "hope" of women in the church may lie in Martha's story. Martha is the one who later leaves her tasks behind and meets with Jesus, without Mary, when their brother Lazarus dies (John 11:20). From this perspective, Martha grows and learns, whereas personal change is not as evident in Mary. ${ }^{2}$ This newer interpretation did not quite match what Lois had said, nor the historical materials I was working through, and I was intrigued by the way Mary and Martha could exemplify two different ways to be Christian women yet also absorb varying motivations and cultural processes of gender, race, and class specific to readers' situated engagements.

1 We give the verses in the King James Version (originally completed 1611), which was the most widely used Bible in the United States in the 1950s. It is close to the American Standard Version from 1901, also available at the time. In 1920s Norway the standard Bible translation was the 1904 version by Bibelselskapet, also close to the King James.

${ }_{2}$ I am grateful to Bertina M. Korte for these interpretations. 
Hovland, too, came across Mary and Martha during her fieldwork, but not in the conversations she had with people whom she was spending time with in a Lutheran mission and aid organization (the Norwegian Mission Society) in Stavanger, Norway, for whom Mary and Martha no longer seemed to be a troublesome touchpoint. Rather, Mary and Martha appeared in the local Mission Archive. The archive does not contain many writings by women, but a number of papers from one woman in the early twentieth century, named Henny Dons, happen to have been saved across several archival collections. As I (Hovland) was following her trail from one archival box to the other it eventually also led me to her published works. I walked across campus to the building that housed the Mission School's library and found her publications from the 1920s still on the shelf. She wrote about, and clearly struggled with, the story of Mary and Martha. In her vision, Christian women had important work tasks in the world. But Dons encountered the challenges of pursuing this work in the story of Luke 10:38-42: did completing work make women too much like Martha?

In this essay we discuss how Lutheran mission-supporting women in 1920s Norway and the 1950s United States read the Bible story of Mary and Martha, as it was variously interpreted, reframed, and circulated through a variety of lower-status written materials. We seek to not only discuss what reading was as a cultural practice within these two communities, but also to develop a comparative analysis of Christian reading and embodiment. We begin by outlining some of the work that anthropologists have done on reading in Christian groups. What we are interested in here, and what we would like to bring to this conversation, is the straightforward observation that while reading cannot be done without words, it also cannot be done without a gendered, raced, and classed body, or without material engagements in the world. Focusing on embodiment can usefully illuminate the intersection of reading and Christian identity-making, which occurs through a variety of material processes. We then present the two cases of women reading the biblical text of Mary and Martha, and, in working through our discussion of these readings, we argue that reading practices are constituted equally by language and materiality (including bodies). In conclusion, we suggest that paying attention to embodied reading yields a fuller anthropological analysis and draws into question the argument that a Protestant semiotic ideology works consistently toward purification.

\section{ANTHROPOLOGICAL PERSPECTIVES ON READING IN CHRISTIAN COMMUNITIES}

As anthropologists we see comparison as always constructed. While we agree that comparison yields the fullest benefit when each source is read in its context rather than detached from it (Cerutti and Grangaud 2017), we would add that these contexts themselves are constructed by the researcher. This process of 
creating contextualization, or framing, occurs at multiple levels: conceptual, methodological, and social. We will begin with the conceptual frame we have created for our own constructed comparison of Christian reading. But, as we suggest later, this comparative process is not limited to the researcher and is in fact central to the experience of reading as readers relate circulating biblical texts, their interpretations, other stories and events, and embodied experiences.

Around a decade ago, Matthew Engelke called for more focus on the "ethnography of reading" in anthropological studies of Christianity and suggested looking at Christianity as a "religion of readers" (2009: 151). He referred back to the edited collection The Ethnography of Reading (J. Boyarin 1993a), which directed attention toward the fact that "reading" is not the same across different cultural moments, and which was part of the broader "turn toward the reader" or "reader-response" approach in the humanities. While neither this edited collection nor the "turn toward the reader" have prompted substantive theoretical conversation within cultural anthropology, many individual anthropologists have nevertheless provided fine-grained ethnographic descriptions of reading practices in different Christian communities. Engelke himself has vividly exemplified the wide range of Christian reading practices in his portrayals of the Zimbabwe Apostolics who do not read but instead live the Bible (2007), and the Bible Society, which is attempting to navigate changing biblical reading practices in England (2013). Another prominent scholar is James Bielo, who has brought together studies on the "social life of scriptures" (2009a) and has studied "collective reading" in evangelical Bible study groups in the United States (2009b) as well as how the Bible is materialized (2018). Other valuable case studies have described Pentecostals "ingesting" words (Coleman 1996), Anglicans using reading to navigate interior fragmentation and coherence (Strhan 2015), and Catholic "lectio divina" (Irvine 2010), and there are many more (Crapanzano 2000; Harding 2000; Keller 2005; Cannell 2006; Kirsch 2008).

Though many authors have described the relationship between bodies and texts, the embodiment of reading has only rarely been explicitly theorized within this literature. A few studies on Christian reading mention gender (most insightfully, e.g., Bielo 2009b: 62-63, 149-51) or analyze reading as a gendered practice (Griffith 2000; 2004), and some consider how Bible reading is informed by embodied postcolonial hierarchies of knowledge (Keller 2005; Engelke 2007), but many studies implicitly describe androgynous readers. While an androgynous body may easily escape theoretical scrutiny, we suggest that positing an androgynous body is itself an analytical move that presumes a type of neutrality or negation of the ways in which embodiment shapes reading. When we refer to embodiment, we have in mind what Rebecca Lester (2005: 45-46) has described as "the 
articulation between cultural processes concerned with the body and the subjective experience of that body as a source of personal meaning." That the body is a rich site for expressing and experiencing forms of devotion, labor, discipline, and divine power in Christian communities has been widely established (Csordas 2002; Griffith 2004; Lester 2005; Klassen 2011; Casselberry 2017). Embodiment in Christian communities concerns issues of race, gender, class, nationalism, sexuality, disability, postcolonialism, illness, and much more, or attention to how "control of the body is always already a site of struggle in social conflict and political negotiations" (Covington-Ward 2016: 9, original italics). These problems have guided our effort to develop an intersectional approach that takes into account the embodied positions and relations that shape the act of reading.

Reading in Christian communities thus fundamentally involves materiality, not only of the text as a material object but also through the bodily act of reading and its entanglement with myriad cultural hierarchies and political-economic processes. Though they have yet to be united under a common theoretical framework, we suggest it is productive to link the embodiment of reading with the rich literature on material religion (for a good conceptual overview, see Meyer et al. 2010). A range of physical and material processes characterize reading, from the sensory dimensions of seeing and handling a text, through the way reading requires occupying space in a room alone or with others, to the influence of the reader's embodied subject position on how the text can be used. Reading's corporeality can also emerge as an explicit object of analysis, such as when Christian texts instruct readers about suffering bodies or bodies to be saved, worked upon, cared for, or made healthy, strong, or desirable (McDannell 1995; Griffith 2004; Lester 2005). These approaches demonstrate elements of what Thomas Csordas (2002: 244) has termed "somatic modes of attention," or a focus on "culturally elaborated ways of attending to and with one's body in surroundings that include the embodied presence of others." Circulating texts, like other devotional objects, can also constitute "sensational forms" (Meyer 2006) that materially link individual acts of bodily piety, reading communities, and the divine (see e.g., Klassen 2011: 59). In short, what we take and expand on from these disparate contributions is the insight that, while reading is always embodied and materially realized, it can involve selective, heightened attention to certain bodily practices, and readers can in turn materially transform their embodied experiences through textual engagement.

We suggest that paying analytical attention to the relationship of reading and bodily praxis complicates implicit assumptions of reading as logocentric or androgynous. Explorations of Christian textual ideologies or language ideologies, that is, cultural theories of how words operate in the world, tend to give less attention to the political-economic structures and embodied 
relations of textual practice (though for a critical reflection, see Bialecki and Hoenes del Pinal 2011). In order to widen the analytical frame, we combine work on "semiotic ideologies" (Keane 2007) and "language materiality" (Shankar and Cavanaugh 2017) to shed light on the important interweavings created across linguistic and material forms - including bodies - in Christian reading. Indeed, though not often analyzed alongside theories of Christian linguistic practice, scholarship on Christian women's organizations has often presumed inextricable connections between textual engagement and the cultural negotiation of tensions surrounding gender, religion, and race (see e.g., Griffith 2000; Casselberry 2017). Similarly, even as these connections have infrequently been theorized, the literature on women's groups supporting international missions critically examines these women as creating not just Christian worlds for themselves but also colonial ideologies on the margins of empire, against a backdrop of social activities that include reading (e.g., Hill 1985; Bowie, Kirkwood, and Ardener 1993; Huber and Lutkehaus 1999).

This set of analytical commitments has also shaped our methodological approaches to doing "ethnography in the archive" (Stoler 2008). How are we as researchers reading about the Christian women who were reading the story of Mary and Martha? Academics are often so used to reading that it can be difficult to defamiliarize this process and to regard both others' and our own reading as social, embodied, and dynamic activities.

Hovland has worked in particular with papers and books authored by one woman, Henny Dons, preserved in the Mission Archive and the library of the previous School of Mission and Theology (today VID Specialized University) in Stavanger. The archive and library are located on a grassy plot of land that also houses the head office of the Norwegian Mission Society (NMS) and is known locally as Misjonsmarka, "the mission field." To access the archive, you walk past an old, white-painted wooden house, which Henny Dons may have been inside when she was employed by NMS from 1917 to 1939 as their "Children's Secretary." Crossing the cobbled courtyard brings one face to face with a statue of Lars Dahle, the patriarchal leader of NMS from 1889 to 1920 , known as høvdingen, "the chieftain." Finally, you enter a modern, zig-zag style building with large glass windows, descend the stairs to the basement, and go through the fireproof doors to the vast archival rooms. NMS has, since its beginning in 1842, preserved words. It is all the more noteworthy, then, that the author of NMS' official centennial history in 1942, John Nome, writing around the time of Henny Dons' retirement, devoted only three sentences to her, out of five volumes. He said that she had written books for children, neglecting to mention her copious published and unpublished writings, focused on women, in magazines, pamphlets, Bible study guides, books, and course materials (Nome 1943: 123, 155). Lars 
Dahle, John Nome, and Henny Dons might all have been surprised to find that the zig-zag building has today been renamed the "Henny Dons House."

I am interested in charting the tensions Dons seemed to be working out, as one individual in the midst of a male-dominated institutional and religious setting in the early twentieth century yet surrounded by the broader social changes of the first-wave women's movement. Here I focus on two of her published works, and I use the method of close reading to think about what is going on in and around these texts. "Close reading" means different things in different disciplines, so let me clarify what it denotes here. I read Dons' texts carefully, paying attention not just to what she said but also how she said it. As an anthropologist, I am especially interested in reading, first, "with the grain" of her text, trying to understand how she perhaps perceived the world. However, from an anthropological perspective there are also advantages to going beyond these insider interpretations and thinking through "mid-level concepts" (Amit et al. 2015). I will draw in some midlevel concepts in the discussion below, such as "work" and "place," which never stray far from Henny Dons' voice, but also draw out our perspective a little more broadly. This allows me at times to do what anthropologists also do, which is to reserve the analytical possibility of thinking critically "against the grain" of what our interlocutors are saying. In the case of Henny Dons, it seems to me that her readings of Mary and Martha had some effects that she herself did not articulate.

Halvorson's reading was also shaped by the material environment of the archive. The 1950s U.S. Lutheran Women's Missionary Federation (WMF) records are stored at the sweeping, tree-lined residential campus of the Evangelical Lutheran Church in America's Luther Theological Seminary in St. Paul, Minnesota. Over the course of my first visits to the campus, I grew familiar with the dusty smell of books and acrid, brewing coffee that wafted through the red-stone library building, where the archive sits on the third floor. Walking the third-floor hallway reveals certain histories of the church. Display cases exhibit cultural artifacts from former mission sites, positioning the archive's extensive written materials within the church's cultural geography of colonial missionization. Because the seminary only began to ordain women in 1970, the century-old building has been retrofitted to be more gender-inclusive: women's bathrooms have since been added to former custodial closets, squeezed sometimes under a raft of pipes. When I first began reading in the archive, a female archival assistant helpfully provided information on how to find one's way around the building, adding these historical details with an ironic wink.

The WMF records have been consciously assembled since the 1970s with an eye to diversifying the collection and highlighting the work of women in the church. But they are nonetheless considered more marginal, rather than central, church records, something conveyed at the time of my research by their storage 
in an overflow space adjacent to the library stacks. In addition, the WMF periodicals themselves had features that encouraged me to adopt specific reading methods. Populated by advice columns, Bible study guides, group activities and prayers, the WMF magazines feature pieces anonymously written as well as those attributed to specific member-authors. Rather than follow a single writer's line of association, I approach the discussion of Mary and Martha for the varying meanings brought to bear across individual accounts, drawing out subtle shadings of difference and perspective. I also examine how, by anticipating the embodied act of discussing the text, often in a group setting, the articles place the material body at the center of their analysis, implying a mutual engagement between bodies and texts. Finally, I engage in "close reading" to evaluate how the articles gesture to and build a discursive public of mission-conscious Lutheran women, such as in their periodic use of a collective "we." In some cases, this "we" refers to all WMF member-readers-implicating readers directly in the problems advanced by the writer - while at other times the "we" even includes Mary and Martha in a trans-historical group of Christian women.

TWO READING COMMUNITIES

In both of the cases examined here, reading acquired significance through Lutheran women's "mission groups," that is, groups of women who gathered regularly in church halls or in homes to support overseas Christian mission activities through prayers and donations. While these evangelical women held personal Bible reading to be important, part of their socialization into how to read the story of Mary and Martha occurred by listening to other women talk about biblical passages or mission events at meetings, and by being encouraged to read women's mission magazines and other literature. This was not a fully "collective reading" practice, since not all women in a mission meeting gave their thoughts on a biblical text (as happens in many evangelical Bible study groups in the United States today; Bielo 2009b), but it was a context in which several women's interpretive voices circulated. Group participants' reading also relied on an architecture of material resources (D. Boyarin 1993), ranging from the printing and circulation of magazines and pamphlets to the ability to pay membership dues and make financial donations to mission causes. Likewise, the intertextual practices of these Lutheran women had material effects by raising funds for mission stations in, for example, South Africa and Madagascar, which was in turn made possible by the political-economic projects of British and French colonization, emerging social democracy in Norway, and postwar adjustment in the United States.

This landscape of women's groups stood in various relationships with formal, male-led Protestant organizations and church bodies. The formal institutional context in many ways held theological authority over the 
questions of "what to read" and "how to read" in the women's groups. This might be referred to as particular manifestations of Protestant "language ideologies" (Bialecki and Hoenes del Pinal 2011) that shaped normative understandings among the women, such as an understanding in the American case that an ethical Lutheran self ought to read and get her children to read. But the texts we consider most closely here-pieces from women's mission magazines, a women's mission pamphlet, and a youth Bible study guide - were all authored by women, and were all examples of "popular," mass-produced literature that was not recognized as belonging to the higher-status genre of scholarly biblical commentary. Thus, while the women's reading practices prompted their own questions and claims around authority, they were enmeshed in "interpretive communities" (Fish 1980) with conflicting social agendas. The consequence was that, even as their texts and communities harbored new possibilities, individual women readers in our two cases were guided and constrained by their communities' (sometimes competing) interpretations.

Our first case is part of the "mission feminism" movement in early twentieth-century Norway (e.g., Mikaelsson 2002). At that time, the early women's rights movement had begun to make inroads in Scandinavia, and small groups of urban, middle-class women in Norway had started forming organizations such as the Association for Women's Right to Vote. At the same time, Protestant mission organizations were employing more single women to send to "the mission field" in Madagascar, Zululand (South Africa), Santalistan (India), and China. These single women mission workers were part of a new class demographic in Norway: a group of middle-class women who remained unmarried and were able to train and take up public, paid employment as, for example, teachers. It was still uncommon in Norway to pay married middle-class women for independent employment; while married working-class women often had to take up public work out of necessity, such as in factories, married women in the aspirational and middle-class organization of the mission instead worked as unpaid "missionary wives." But the growing group of salaried single women, including female teachers, presented new possibilities. In this context of social changes, several Lutheran women in Norway began advocating for the increased status of women in Christian organizations, especially in NMS. These women achieved some of their early goals in the first decades of the twentieth century, such as securing women's right to vote in NMS, and establishing a school for single women missionaries. Yet they operated within a context of piety-informed, evangelical, mission-supporting Lutheranism that otherwise often promoted more conservative gender patterns. For example, NMS did not allow a woman to be employed as an ordained pastor until 1990 (later than the state church, the Lutheran Church of Norway, which ordained its first woman pastor in 1961). 
An interesting aspect of Lutheran women's advocacy in the early twentieth century is that some of them lobbied for greater women's status in tandem with adopting new language practices. For example, the single, middle-class, urban women who joined the new Female Teachers' Mission Association decided to hold monthly meetings in which they would not come together to work on crafts, as had been the common practice in other women's mission groups. Rather than sell crafts to raise money, they instead paid an annual membership fee from their own teacher's salary and discussed which mission society to donate to. At their meetings they invited one woman to give a lecture while the assembled women sat still and listened. The speakers often explicated the meaning and application of one Bible passage. These were new speaking, listening, and reading practices for an all-women group, and they resembled the practice of commenting on biblical passages that had previously been the reserve of male theologians in published works, or male pastors in the pulpit.

Henny Dons was frequently invited to give talks at the Female Teachers' Mission Association groups, as well as at women's mission groups affiliated with NMS and other organizations. At the end of 1921 she reported that she had spoken at more than one hundred meetings that year. ${ }^{3}$ This extensive meeting activity tells us that Dons' reading of Mary and Martha and other biblical texts, and her writing about these texts, took place alongside new speaking and listening practices in women's mission groups. As a middleclass, single woman, trained as a teacher and then employed by NMS as their Children's Secretary, she had been able to adopt a new approach to reading the Bible: she could do so in the form of authoritative explication to a semi-public, all-women audience. And, in the context of supporting overseas missions, her talks could also be published as, for example, Bible study guides. In sum, when we say that Henny Dons and her contemporaries were "reading" the story of Mary and Martha, we are referring to a web of new and interlinked language practices - speaking, listening, reading, and writing - that some Lutheran women in Norway began engaging in around the turn of the twentieth century. These were negotiated within a larger context of institutional, religious, and societal shifts regarding what Christian women could do with their embodied identities. Material practices were now becoming possible that only half a century before had been largely unthinkable, such as a woman's voice lecturing on the Bible, or a woman's body working in public for salaried pay without loss of social standing.

Our second case focuses on practices of reading, writing, and discussing the story of Mary and Martha in Lutheran women's mission groups in the 1950s

\footnotetext{
3 Henny Dons, “Aarsmelding for 1921,” 10 Jan. 1922, box 430-8, Innkomne brev hjemlandet 1921-1922, Generalsekretariatet 90, Hjemmearkiv 1920-1970, NMS Arkiv, in the Mission Archive, Stavanger.
} 
United States. ${ }^{4}$ Here, we examine articles published mainly in the magazines of the separate Women's Missionary Federations (WMF) of the Lutheran Free Church (LFC) and the Evangelical Lutheran Church (ELC). Both churches were historically Norwegian-American Lutheran and, since 1888, had raised funds to support paid single women missionaries and unpaid married missionary women in Madagascar.

Reading mass-produced English-language materials on foreign mission work and on a variety of everyday matters of Christian faith was gaining popularity in the 1950 s as not only a Lutheran but also a white evangelical, middle-class practice. ${ }^{5}$ Postwar Lutheranism was influenced by the neoevangelical movement, spearheaded by Billy Graham's rise to national prominence in 1949. Neo-evangelicals built a national movement partly by publishing Christian books and especially missionary stories for broad popular consumption, such as Elizabeth Elliott's well-known 1957 book Through Gates of Splendor (Long 2003). ${ }^{6}$ In addition, ethnically marked European Americans like Norwegian Americans were affirming their participation at this time in shifting notions of postwar whiteness and economic and social mobility in which European ethnic identities began to matter less (Brodkin Sacks 1998). Though many individuals still spoke Norwegian, English had become the dominant language of worship in the ELC and LFC in the previous generation. Reflecting increased financial stability, the postwar WMF organizations moved away from collecting an annual membership fee (thirty-five cents in the mid-1930s) to eliciting "freewill offerings." 7 This shift symbolically emphasized the individual ability and decision to contribute financially to church causes. Moreover, WMF writers' focus on devoting time to church service and household labor, even if they also held some part-time paid employment or worked on family farms, was a testament to their middle-class aspirations and possibly also their household finances (see also Yohn 2002). Collectively, these features likely made WMF participation a sign of middle-class privilege and limited lowerincome Midwestern Lutheran women's involvement in the organizations.

\footnotetext{
${ }^{4}$ As a result of demographic and political changes in American Lutheranism, this period corresponds with the final years of the federations themselves. The ELC and LFC mission auxiliaries ultimately became part of a larger organization, American Lutheran Church Women, after several church mergers in the early 1960s (Lagerquist 1987).

${ }^{5}$ Due partly to this influence, American Lutheran churches reported increased membership during the "revival of the fifties" (Nelson 1980: 481).

6 The ELC's Women's Missionary Messenger made Elliott's text its January 1958 "book of the month" across nationwide chapters.

${ }^{7}$ Brief references to members' increased financial stability are present throughout WMF publications. For instance, when eliciting donations to fund missionaries' daily salaries, the 1960 LFC WMF Program Helps observes: "Remember that if our women were able to give two dollars in the days of the depression we should be able to give even more now" (15). WMF Collection, Evangelical Lutheran Church in America, Region 3 Archives.
} 
In the WMF organizations of the 1950s, written items were themselves an important material medium, linking their dispersed membership throughout the Upper Midwest and other regions of the United States. ${ }^{8}$ On one hand, this can be seen in the WMF ELC budget for 1958-59, which earmarked nearly as much money for literature $(\$ 54,775)$ as for actually funding the work of foreign missionaries $(\$ 75,164)$. On the other hand, reading was painted in WMF publications as an important spiritual exercise that allowed each Federation member to become more knowledgeable and "mission conscious," thereby incorporating names and specifiable facts into one's prayers (see also Griffith 2000: 29-30). ${ }^{9}$ A 1959 Federation publication reminded readers that Jesus "requests prayers for specific things" and cited Luke 18:41, which recounts how Jesus, when entreated with a spoken appeal, restored sight to a believing blind man on the road to Jericho. ${ }^{10}$ By reading missionaries' field accounts and converting these stories into repeatable artifacts of knowledge, one could increase the efficacy of intercessory prayer, or supplications made on behalf of people not immediately present. Through its ability to overcome space and time, intercessory prayer was described by one writer as a "secret service for others" that offers "unlimited possibilities for each of us.",

Cultivating spiritual self-development through reading was depicted not only as critical for WMF readers themselves but also, due to the publications' valorization of the gendered role of mothering, as a key dimension of child-rearing. Exposing children to a spiritually empty environment was compared to feeding them an endless stream of cake, cookies, and sugary candy, with one writer starkly warning in June 1955 that criminality might be the outcome in adulthood. ${ }^{12}$ This article's parallel between the spiritual diet and food consumption extended to other claims as well, such as the recurring idea that the greater one's intake of nourishing Christian reading and the more self-discipline enacted in bodily matters like eating, the more like a missionary one or one's children could become. ${ }^{13}$ Across these articles the serious work of "Christian nurture" was placed

${ }^{8}$ Local chapters of the federations were encouraged to produce 100 percent subscription rates to the magazines WMF Bulletin (NLCA) begun in 1934, WMF Quarterly (LFC) begun in 1939, Women's Missionary Messenger begun in 1946 (ELC), and Women's Missionary Outlook organized in 1931 (ALC).

91956 Program Helps, LFC WMF, WMF Collection, p. 23.

101959 LFC WMF Annual Publication, WMF Collection, p. 31.

11 Ibid.

12 "In Your Home You Can Help Your Child Stay Mentally Healthy," by Dorothy Anderson, June 1955, WMF Messenger, WMF Collection, p. 8.

13 In the 1949 LFC annual publication, an anonymously penned article stated, "Our earthly journey is the road of sanctification. The soul is constantly struggling to conquer the body, by refining the appetites, by curbing the passions, by elevating the desires, and by taming 'the root of all evil' in order to better serve God and His Kingdom on earth" (20). WMF Collection. 
squarely on WMF readers' shoulders, who were expected to develop the "taste for good reading" in their children. ${ }^{14} \mathrm{WMF}$ publications, then, positioned their readers in a moral hierarchy: they could turn to their WMF chapters for spiritual development but, due to the dearth of discussion of fathers as parents, they bore the main responsibility of nurturing that same spiritual growth in their children. These injunctions carried a clear self-referential quality, too, because it was church publications, like the Women's Missionary Messenger, that were imagined as necessary to feed one's spiritual appetite and to help materially make a Christian home. This connection was made explicit in an early article that championed the Messenger as the "best publication that can come into the home." 15 In sum, for WMF readers, reading was a practice with clear material effects and implications; it was closely related to aiding foreign missionaries from afar, maintaining Christian homes, and spiritually nourishing white middle-class Christian bodies - a set of activities that, in turn, emerged through and shaped wider cultural and religious transformations in 1950s America.

\section{READINGS OF THE STORY OF MARY AND MARTHA}

Let us now turn to different readings of the story of Mary and Martha among our two reading communities, growing out of their historical-material circumstances and the hermeneutic strategies shaped by these contexts. In general terms, we might say that when these women approached the Bible, which they regarded as the sacred word of God, they sought to turn the word-as-thing (the typed letters on the page) into word-as-event (an effect in the world). ${ }^{16}$ One of their strategies for doing so was to look for ways of identifying with the biblical characters, as they worked with the connection between textual characters and self-construction that has come to be taken for granted in the modern period (Steedman 2009). The women's "affective identification" (D. Boyarin 1993: 19) was multi-layered: for example, they wished to connect with the story's original word-as-event in which Jesus spoke to Martha, and also to have this be eventful in their own lives through using Martha and Mary as role models or foils. This reading strategy opened up a range of "relational possibilities" (J. Boyarin 1993b: 212) as the women decided, for example, how to apply the pronouns "we," "you," and "them" as they read and repeatedly recontextualized Martha and Mary.

\footnotetext{
14 "Christian Nurture Is Needed," by Mrs. Otto Flom, Sept. 1955, WMF Messenger, WMF Collection, pp. 23-24.

${ }^{15}$ LFC WMF 1943 Annual Publication, "Unto His Glory (That He Might Be Glorified)," WMF Collection, p. 10.

16 These evocative terms come from Walter Ong (2012[1982]). But, while he uses them to delineate a separation between oral and literate cultures, we instead see the two as more closely intertwined (following J. Boyarin 1993a), even in reading practices in such a highly literacyconscious tradition as Lutheranism.
} 
This practice of reading the Bible for human examples has also been observed in anthropological studies of other Christian communities. For example, Naomi Haynes describes how Pentecostals in Zambia engage in "typological reading" (2020: 58) of figures in the Bible. In this reading practice, the biblical examples from the past are "relived" (ibid.: 57) here and now, thus creating a sense of an "expansive present" that folds into itself the past and the anticipated future. Haynes argues that this "reliving" goes beyond mere identification with a biblical character and instead gains "performative force" (ibid.: 59), for example in the instance of a Pentecostal bishop who models his life story on the biblical figure Ezekiel, "Bishop Ndhlovu becomes Ezekiel" (ibid.: 60; see other examples in Harding 2000). Similarly, Andreas Bandak describes the significance that examples take on among Eastern Catholics in Syria as they strive for Christian character formation. Here too, the Bible is used as "a web of exempla" (2015: 54) some examples to be imitated, some not to be imitated, and some to simply regard with awe. Bandak shows how singular biblical examples can be joined with other examples, including exemplary saints, to form a series. He argues that the power of a series of examples is that the reader or listener is invited to respond and thus to become part of the series in the here and now. As Bandak puts it, "the example is not finished" (ibid.: 57).

For the Protestant women in our two cases, the biblical examples of Mary and Martha similarly held power because they were read as "not finished," and requiring a "relived" response.

Norwegian Lutheran Mission Women Reading Mary and Martha in the 1920s

Let us start with Hovland's case, set in the context of Lutheran mission-supporting women in 1920s Norway. I (Hovland) will examine two texts written by Henny Dons for this readership, in which she discusses Mary and Martha.

The first text is an eight-page essay titled "The Woman's Task and Work in the Mission," published by NMS in 1923 as part of a twenty-two-page pamphlet on women and mission (Dons 1923). Dons' essay is likely based on notes from lectures that she gave in meetings for women's mission groups across Norway. Her opening sentence is: "Our Bible tells us in so many ways that we women too have a task and a place in the work for the mission" (ibid.: 3). She begins by tracing the task of women as presented in the Bible, first discussing some female characters in the Old Testament, including Deborah in Judges who, Dons says, shows us a combination of great strength of faith, courage, and love. Dons immediately ties the abstract quality of love to the embodied idea of motherliness: "it is the warm motherly heart that God has given the woman" (ibid.: 4). While she refers to motherliness in a figurative rather than literal manner here (she herself had no children, and only single, childless women were officially employed by NMS), figurative motherhood is nevertheless an embodied state that, in her 
view, only people with a female body could take on. Thus she presents motherliness - mental, emotional, and physical care - as one of the unique contributions that women could make in homes as in society at large. She ties this figural, embodied idea of motherliness to the figural, embodied idea of "place": "It was Christ who gave us [women] the place that God has meant for us as humans" (ibid.: 4). She then mentions a number of New Testament texts that apply, in her reading, particularly to women's emotional and physical comportment, including the exhortation that women are to be "the fragrance of Christ" wherever they go. Then she adds: "But we are also meant to witness about Christ with our words" (ibid.: 5, her emphasis).

The importance of words brings her to Martha and Mary. She does not start with the verses from Luke 10, in which Mary is sitting at the feet of Jesus and listening to his words while Martha is occupied with housework. Instead, she turns to John 11, in which Jesus raises Lazarus, the brother of Mary and Martha, from the dead, and says to Martha: "I am the resurrection and the life" (John 11:25). These are "wonderful words," Dons comments, and the fact that they were spoken to Martha carries great importance: "it seems Jesus confided to a woman what he had not yet confided to anyone else" (1923: 5). Only after establishing Martha's importance in this way does she turn to Martha's work in Luke 10. In this account, Martha complains to Jesus, asking him to tell Mary to help her with the housework, and Jesus responds: "Only one thing is needed." Dons frames the account by reminding readers that women should wear the "jewelry" of 1 Peter 3:4: "the heart's hidden self with a gentle and quiet spirit." She elaborates: "For every worker in the Kingdom of God, woman as man, it always first depends on what we are. Christ must live by faith in our heart" (ibid.: 5, original emphasis). This helps her interpret Jesus' response: “This was what Jesus meant when he said to Martha: 'Only one thing is needed.' The hidden life in God through Jesus Christ is what is absolutely needed. Therefore we women, if we are to find our task and place in the work for the mission, must first have found our place at the feet of Jesus" (ibid.: 5-6).

In other words, Dons suggests that Jesus' response was a reprimand: Martha, as opposed to her sister Mary, had not focused on that "one thing"- the "hidden self," "what we are," the "quiet spirit" that was women's "jewelry" - which was to be found "at the feet of Jesus." Martha's working body did not embody the "one thing," but Mary's seated body did. To underscore this placement, Dons goes on to create a series of examples (Bandak 2015) of other women in the New Testament who similarly found their place "at the feet of Jesus," including the woman who was healed of bleeding (Matthew 9), the woman who anointed Jesus (Luke 7), and the woman accused of adultery (John 8).

However, Dons herself was a working woman, and in her reading of Martha and Mary she does not want to discount the value of women's work. 
Instead, she traces a layered relationship between women and Jesus. She sees Mary's placement as the ideal relationship, and it is given in the forms of speech, place, and bodies: Jesus is speaking, she is listening, at his feet. This placement might imply intimacy or subservience. But it could also imply the woman's spiritual knowledge or institutional power, insofar as Jesus in this configuration becomes the woman's teacher or sponsor. Perhaps this is the configuration Dons has in mind when she says that women have "the same right to salvation" as men: "This is our right, also for us women-saved by Christ, freed in Christ, clothed in Christ, called to service for Christ" (1923: 8). She reasons further: "A large host of women are now working for Jesus out there in all the mission fields. The woman is out there as missionary wife, teacher, doctor, nurse, evangelist, Bible woman, congregational worker" (ibid.: 9-10, added emphasis). Here she has turned the intimate, subservient position "at the feet of Jesus" into an argument for women's entrance into the mission's paid labor force. In conclusion she outlines the task of "us women" by dividing the world's women into two groups: Christian and non-Christian. She gives several examples of what she sees as the denigration of non-Christian women in other parts of the world, from "heathen" women in polygamous marriages, to Muslim women in the "prison of the headscarf" (ibid.: 8-9). She argues that non-Christian women can only break "free" if they "hear the gospel from the mouth of women" (ibid.: 10) - a powerful argument, in her view, of the importance of "sending out" female bodies, and not just male bodies, as mission workers.

The second text I will look at is Henny Dons' book Women of the Bible: Bible Studies, published in 1928 as "studies" for youth members of the YWCA and YMCA in Norway (Dons 1928: 5). Dons included a study of Martha and Mary in Luke 10. While in the 1923 pamphlet Dons implied that Martha should have found her place at the feet of Jesus, in the 1928 Bible study she slightly alters her reading. She suggests to her youth readership that perhaps the work Martha was performing was "being busy with getting food for all the guests," and the problem was that "in busyness it is easy for "struggle and unease' to enter, and then something becomes broken in you" (ibid.: 83). Jesus' response to Martha shows how he "mildly and lovingly helped her by righting her again." Here Dons explicitly comments that Jesus' message was not that Martha should cease her work. Rather, he was pointing to the importance of "keeping the stillness in the midst of the busyness [...] stillness with the Lord" (ibid.: 83). Moreover, Dons notes that Martha must have taken Jesus' words about the "one thing needed" to heart and changed her attitude right there and then, since she did not protest his words. This, she implies, is to Martha's credit. Dons goes so far as to say that Martha has performed the important role of "preacher to all generations since" about the "one thing needed" (ibid.: 84). While in the 1923 pamphlet Dons concluded that Martha failed to focus on the "one thing needed," 
in 1928 her reading led her to argue that Martha is a "preacher" about the "one thing" to all who read the Bible. Her word choice is noteworthy, since it was still not common in 1920s Norway for women to preach to mixed-gender gatherings.

Dons elaborates on this more positive reading of Martha by re-reading Martha's relation to Mary. She explicates the relationship between Jesus and the sisters, Mary and Martha, who both received him in their home and spoke with him: "these sisters loved Jesus and Jesus loved them. This was the relationship of intimate friendship between them and Jesus, so that they received Jesus, just as Jesus also received them" (ibid.: 84). Then she argues that on the basis of this relationship there is no difference in status between Mary and Martha:

It is no less a love that receives than gives. In love the two things become one, so that the one who receives gives, and the one who gives receives. In this way there is, therefore, no difference between these two sisters. Martha and Mary.-And when we view them in this light, seeing them as types of women in the new covenant, we find that Jesus Christ sets women free to serve him, both in the material and spiritual aspects of life. Martha's service was focused on the material, Mary's was of a spiritual character. A woman's place is in the tasks of the home, but it is also at the feet of Jesus. And it is absolutely necessary that the women of the new covenant find this place. (ibid.: 84)

In contrast to the 1923 pamphlet, Dons now reads Martha and Mary as demonstrating two positive "types of women," and she now describes the "place" of women as an actionable combination of both Martha and Mary. Dons' text leaves some ambiguity regarding how exactly individual women should seek to interweave these two typologies in their own life. While in the 1923 pamphlet she ended with an argument for why women's bodies were needed in the mission, she ends here by showing the importance of women's domestic labor. Again she has returned to women's embodied piety, but a certain impasse remains, since Dons does not say how women's place at home and at the feet of Jesus might mesh with their work as nurses and teachers in "the mission field." She doubtless wanted the young women in her readership to also consider their potential place in the global mission, perhaps even as preachers. Her second reading of Mary and Martha hints at this but shies away from fully working it through.

\section{American Lutheran Mission Women Reading Mary and Martha in the 1950s}

In WMF publications of the 1950s, the complex relationship of Christian women's work and worship was played out most incisively through the biblical figures of Mary and Martha. In a 1956 advice essay titled "The New Year Inventory," by Mrs. Martin J. Olson, Mary was appreciatively described as someone who "sat at the Lord's feet and listened to what He was saying" in quiet devotion, looking to "the Word" for guidance and completing action with God in prayer rather than engaging in a flurry of activity as did her 
sister Martha. ${ }^{17}$ One earlier, 1943 article even exhorted readers to "not think for a minute that Mary swept the dust under the rug or left the beds unmade, the meals unplanned," but that she had "learned the secret of poised Christian living - she put "first things first." 18 While it clearly upheld Mary as a moral example, this statement could also be read as urging readers to discipline or hide their Martha-like tendencies in order to appear poised. Although Martha was regarded as a woman of faith in her own right, the critical way many WMF writers of the 1950s approached her suggests a wider concern with gendered activities of household work and church service that were done without signaling an interior basis of faith. These accounts also reveal a semiotic ideology of bodily practices: slow, deliberate work expressing deep and abiding faith while busyness indexes a potential lack of the faithful contemplation necessary for cultivating spiritual commitment. One earlier article in the LFC WMF annual publication in 1945 even warned, "No doubt we have many Marthas who so burden themselves with services for Christ that they do not find the time to listen to what He has to say until He must rebuke them."19

Writers tied the contemporary relevance of the biblical story not only to becoming self-educated and learning the proper "spirit" of service but also to scrupulously using time and recognizing the underpinning selfishness of excessive worry. ${ }^{20}$ One Federation essayist guided readers through a Bible study of Luke 10:38-42 titled "Freedom for Service" by advising:

When we think of Martha, we think of service, for each time we meet her in the Bible, she is serving. Service is beautiful when it is given in the right spirit, but it must be for love's sake. It was only when Martha got so busy serving that she forgot Him whom she was trying to serve that her work became a burden. If Martha had taken time for a few minutes of quiet resting at the feet of Jesus on that day when she was to have Him as her guest, her ruffled nerves would have been soothed, and she would have seen things in their right relationship. ${ }^{21}$

The "right relationship" commended by the author distinguishes the knowledge gained by "quiet resting at the feet of Jesus," a metaphor for Bible reading and study, from the forgetful busyness that could plague the reader and prevent her from seeing the deeper value of her work. In this sense, serving was not necessarily the problem, but one had to attain and demonstrate a kind of spiritual "freedom" from serving in order to then successfully pursue the work. Alluding to the story of Mary and Martha, one Federation publication

\footnotetext{
17 “The New Year Inventory,” by Mrs. Martin J. Olson, LFC WMF 1956 Annual Publication, “A Woman's Year,” WMF Collection, p. 10.

18 October 1943, ELC Women's Missionary Federation, Program Helps, WMF Collection, p. 59.

19 LCF WMF 1945 Annual Publication, "Give Me A Light," WMF Collection, p. 11.

20 See, e.g., 1956 LFC WMF Annual Publication, WMF Collection, p. 10.

21 LFC WMF 1957 Annual Publication, WMF Collection, p. 51.
} 
went so far as to caution readers that the root of sustained and unfocused busyness was none other than Satan, who could "trick us into such a full program of benevolent works that we would have no time at all for the most necessary part of our program - to be still before God and renew our strength there." 22

Not all commentators morally polarized Mary and Martha in the same way, however. In the cheekily titled "Just a Housewife!" one writer, Mrs. Philip Halverson, argued that people have mistakenly believed Martha was chastised by Jesus for her behavior, but in fact a careful reading reveals that "the attitude and manner in which she went about her work" was problematic. ${ }^{23}$ Looking across several articles also discloses a certain kind of empathy for or identification with Martha, who is often portrayed as more flawed and disarmingly human than Mary. For instance, the 1957 "Freedom for Service" Bible study observes, "Does it seem to you that God sometimes is slow in coming when you call upon Him in your need? Learn a lesson from Martha and express confidence in Him." 24 Additionally, in a close reading of Luke 10:40, the author Mrs. Marcy Ditmanson declared, "Becoming all 'balled up' with too much to do, Martha snapped unpleasantly at those she loved best. This is a familiar experience to us, too, isn't it?"25 In terms of the sheer ink spilled on Martha, authors also convey a keen curiosity about her, and they do not reference Mary as often. The same 1957 Bible study, for example, unexpectedly ends with the following instruction to Bible study participants: "There are three pictures of Martha in the Bible. Two of these are found in the book of John [11:20-27 and 12:1-3]; one in the book of Luke [10:38-42]. To get a better understanding of her character, let us briefly study all three of these pictures." ${ }^{, 26}$ The idea of looking contemplatively at Martha's portraits for insight speaks to the open-ended and curious way WMF publications of the 1950s approached her, even as her behavior was censured. Rather than reject Martha's example altogether, the 1954 essay on Martha's problematic manner concluded that Lutheran believers needed to unite and iconically embody Martha's "hands" and Mary's "heart."27 Here, the writer signaled an awareness that women's work ("hands"/body) would not cease but could possibly be spiritually reconciled or venerated ("heart"/soul).

\footnotetext{
22 “Prayer," by Mrs. Iver Iverson, 1951 LFC WMF Annual Publication, "A Time for Decision," WMF Collection, n.p.

23 LFC WMF 1954 Annual Publication, WMF Collection, p. 49, original italics.

24 LFC WMF 1957 Annual Publication, WMF Collection, p. 52.

25 “I Take a Vacation,” by Mrs. Marcy Ditmanson, 1956 LCF Program Helps, WMF Collection, p. 32 .

${ }^{26}$ LFC WMF 1957 Annual Publication, WMF Collection, p. 51.

27 LFC WMF 1954 Annual Publication, WMF Collection, p. 49, original italics.
} 
Readers' empathetic identifications with Martha were also encouraged by WMF publications' frank discussion of the labor of housework. In a 1959 Bible study entitled "Ask with Endurance," the unidentified author bemoaned, "Satan often so fills us with the feverish desire to accomplish some homemaker's task that we do not realize until the day is nearly gone that we forgot to pray. I have found myself being almost compelled to write a letter, or to begin the washing, or to make a phone call (suddenly extremely important!) just when I had decided to give some time to prayer." ${ }^{28}$ WMF members were motivated not only to see a parallelism between Martha's experience and their feelings of being overburdened with work in the home, but also to re-imagine their homes as fields for serving God, in a way that could echo the far-off fields of women missionaries. A 1944 essay described the importance of "kitchen stewardship" and observed, "Since I've no time to be/A saint by doing lovely things/[...]Make me a saint by getting meals/And washing up the plates/[...]Accept this service that I do-/I do it unto Thee." ${ }^{29}$ The 1954 essay titled "Just a Housewife!" featured a prayer in poetic verse that further spelled out these connections. The first stanza lamented, "How can I live for Jesus,/My Lord, Whom I adore,/When my domain of service/Lies within my kitchen door?/I long to serve Him freely/In a fuller, better way,/But just to be a mother/Keeps me busy every day." After three stanzas that quoted Luke 10:38-42 and referred to Jesus as a "guest within my kitchen," the prayer closed with the following lines: "I'll teach those near and dear./While others serve in foreign lands,/My mission field is here."30 Such lines wove a durable knot between serving in an exemplary way and the home spaces in which WMF members were presumed to spend the majority of their time. They could, in other words, sacralize their home spaces and kinship relations and make them into quasi-public testaments to their service, even occupying a venerated role akin to (but not the same as) a foreign missionary.

Thus, WMF articles indirectly provide a window into the material environments and work practices of their readership, who were primary caretakers of their homes and children. Martha was a ready biblical character through which to refract and reflect readers' burdensome obligations of sweeping, cleaning, childcare, and preparing food. Their Bible study meetings and monthly periodicals could be a reprieve from these obligations, but also became challenging to fulfill because of the unacknowledged labor the women were pursuing. Martha and Mary created a space of dialogue for not only negotiating the integration of Christian piety and household work,

281959 Program Helps, ELC Women's Missionary Federation, WMF Collection, p. 45, original emphasis.

${ }^{29}$ LCF WMF 1944 Program Helps, WMF Collection, p. 71.

30 LFC WMF 1957 Annual Publication, WMF Collection, p. 49. 
but also beginning a process of venerating work that had been considered lowly and profane. It made the material environment of the home, as much as the foreign fields of the missionaries about whom WMF members were also reading, into a space in which one could engage in religious work and re-envisioned household activities, whether a cooked meal or tidy kitchen, as potential manifestations of personal piety.

\section{A COMPARISON OF EMBODIED READING PRACTICES}

A central theme that emerges across both of our cases is how, for 1920s Norwegian and 1950s U.S. mission women, readings of Martha and Mary were inextricably tied to cultural ambivalence surrounding women's work. These reading practices were themselves a space, however fleeting or limited, for working out the relationship of work and gender for readers' Christian observance. Through Martha's household activities in particular, readers' own laboring bodies could become visible as a subject of attention, not as crystal-clear, fully apparent wholes, but as parts and glimpses, viewed at angles through the dynamic play between their ordinary responsibilities and the text, its characters and ongoing, changing frames and interpretations. Therefore, their reading carried a range of "relational possibilities" (J. Boyarin 1993b: 212), not only in terms of the prospects of doing gendered work, but also for their exploration of the shifting possibilities of relations with themselves and with "others." In both of these networks of women there is a tendency to voice critical views of Martha, interpreting the story in Luke 10 to mean that Jesus was criticizing her work (or her way of working). However, the criticism never goes so far as to result in an outright rejection of Martha's work.

Yet, subtle but significant differences come forward across our two cases. In the Norwegian case, there is some ambivalence around this criticism of Martha. Henny Dons put effort into re-thinking Martha's work as "giving" and therefore "love." Dons' reading of Martha occurred in dialogue with an expansion of women's public, paid work in NMS, a trend that Dons wished to support. At the same time, her readings of Martha and Mary never fully resolved the tension between women working inside and outside the home, though her description of women's ideal placement at Jesus' feet and the religious "right" this afforded them perhaps echoed the evolving public discourse on women's political rights in early twentieth-century Norway.

In the American case, on the other hand, we observe a more cautious reading of the implications of women's place, this time perhaps echoing the broader dampening of public discourse on women's roles and rights in the 1950s United States, as the postwar period reinforced more conservative gender patterns again. Work is portrayed as essential to WMF members' roles as wives, mothers, and mission-supporting church members - even if taken for granted-yet they are expected in one dominant WMF reading of 
Mary and Martha to manage and even erase the social visibility of that work. Successfully minimizing their own embodied work of housekeeping and child-rearing in this framing-not appearing consumed by it, stressed or complaining, while nonetheless completing it - can lead to a position where they can be socially recognized as contemplative, faithful Christian women. To some degree, we see in the WMF publications of the 1950s a retrenchment in the morality of women's caretaking roles and a subtle devaluing of this work as labor. Yet we can also see writers seeking ways to reconcile these gender expectations with women's intellectual study and work in the church. Embodied gender roles thus emerge as both intimately informing American Lutheran women's reading of Mary and Martha but also as a problem that must be worked with and worked out through the reading process itself. In sum, while Martha is openly identified with by American WMF members, we see a more explicit validation of Martha's work in Dons' later writing. However, both groups' ongoing, unresolved readings of Martha's work allowed them to fit in with their Protestant institutions while at the same time subtly breaking out of them.

The women readerships seem overall to have written and read less about Mary. Her intentional non-work in the story, in order to take her place at the feet of Jesus, was more easily read as "good." However, it also left some nagging questions. Both non-work and work were tied to women's bodies. This highlights somewhat counterintuitively in the publications' framing how the body is actually central to reading, but that for women in particular bodily labor must be subsumed or managed socially to index a bodily praxis of contemplative faithfulness. Women's work was supposed to be "quiet," in "stillness," sometimes even in "secret" or part of the "hidden life." This tension surrounding women's bodies was not necessarily resolved. However, the same tension can also be seen to legitimate women's contemplative service in the church and carve a path for women's intellectual growth and study.

A second theme is that these written interpretations of the Mary and Martha story speak not only to the shifting gendered dimensions of sectarian and political practice, but also to the way gendered archetypes of Lutheran service were covertly raced and classed in both 1920s Norway and the 1950s United States. However, as before, important cultural differences emerge across our two cases. In the Norwegian case, the women readership found ways of relating to a range of "others" who were encompassed and subsumed in the project of "we women." The most obvious "others" were the groups referred to as "heathen women" and "Muslim women." Dons emphasized the responsibility of Norwegian Christian women to take up women's work in the mission in Madagascar, Zululand, Santalistan, and China, or to support this work, in order to fight for the "right" of these other women around the world, a discourse which has had an enduring place in both secular and faith-based forms of Western feminism (Abu-Lughod 
2015). The "other" women became necessary characters in order to demonstrate the importance both of Western Protestant women's work (like Martha) and their place at the feet of Jesus (like Mary). Although Dons does not spell it out, these opportunities were tied in varying degrees to social class, since the possibility of donating financially, paying for membership fees or magazine subscriptions, or taking up paid employment as a single woman, was greater for middle-class, urban women. There is thus a hidden "other" in her reading, namely Norwegian women who had fewer means to take part in these specific forms of cultural capital.

By contrast, the American periodicals do not reference faraway or nonChristian women when reading Mary and Martha (though such women do receive attention in other articles). Instead, a different range of "others" materialize in the pieces we have analyzed. American writers give greater, indirect attention to the heterogeneous racial and religious landscape of 1950s America. One example is the use of Martha's service to subtly explicate a "Catholic position" toward good works, drawing out the notion that Lutheran service work by contrast is ultimately, in the words of one January 1955 writer, an "expressive sign of a Christian life," and thus not a pursuit meaningful on its own. ${ }^{31}$ Another example is that the specter of criminality - a longstanding figure racialized Black in the American imagination - is raised by WMF writers as the moral opposite of the wholesome, white, middle-class Christian home. Imagining the white Christian home as a closed, protected, and distinctive space mirrored the closing off of neighborhoods and suburbs as white enclaves in the 1950s. Seen in this context, the Mary and Martha story made WMF readers crucial keepers of this raced, classed, and gendered space and made them accountable for Christianizing it. We could also possibly interpret the account of Mary and Martha as a story that consolidated white, gendered, Anglo-Protestant, middle-class sensibilities and styles, such as moderation, composure, and self-restraint. Across WMF articles from this time period, Mary is repeatedly cast as the figure who best embodies and instructs these sensibilities, in contrast to Martha.

A final theme, closely related to the one above, is the critical importance that seemingly parochial Norwegian and American debates over Christian women's roles and bodies had in the operation of empire globally. For both groups of Protestant women, their dominant racial and class ideals of Christian gender roles were exported to colonial and colonially influenced mission sites in Madagascar, South Africa, India, and China. Sometimes this happened through the global travel of women missionaries, such as Lois,

\footnotetext{
31 “Our Offering of Self-Denial,” by Mrs. J. B. Shefveland, Jan. 1955, WMF Messenger, WMF Collection, p. 12.
} 
who occasionally wrote articles for WMF publications beginning in 1952 and spent thirty years in southeast Madagascar working with Malagasy Lutheran women's study groups. But more commonly this process was a slow, contested form of influence, as missionaries overseas socially reproduced their own changing, implicitly and explicitly held values and sensibilities of the white middle-class, heterosexual, Christian home with its gendered spheres. At times, this complex influence occurred even as female and male mission workers explicitly critiqued Western influences in "the mission field." While Protestant women reading at home could not readily act upon all of these arenas, they took part in placing women's bodies at the center of these projects, often unaware of the far-reaching effects of their readings. For example, they took on the figure of "the Christian mother" who came to stand for the possibility of "a Christian home," which in turn became metonymically linked to the idea of a "Christian" or "civilized nation," and finally provided one of the justifications for the uneasy linking of Protestant missions and colonial projects in the early to mid-twentieth century.

\section{CONCLUSION}

Our comparison between different readings of Mary and Martha among two groups of Protestant women facilitates a tracing of fine-grained similarities and differences. In conclusion, however, we return to the larger question: What does the comparison tell us about how we might think anthropologically about reading in Christian communities?

Let us consider a thought experiment for a moment: If we were to implicitly assume androgynous readers in our two Christian communities, what would our conclusion have been? Perhaps these cases might then have been analyzed as instances of Protestant purification. The Protestants in question read the Bible for human examples-Martha and Mary of Bethany - that, in the course of reading, are seamlessly turned into typologies: "a Martha" or "a Mary." Mary is usually (though not always) regarded as the more virtuous exemplar in these two communities, and she is also the most abstracted: her virtue is simply being "at the feet of Jesus," focused on "the one thing needed." She is the least mired in the material minutiae of the ordinary world. The readers who strive to identify with her might, then, be assumed to be striving for similarly abstracted virtue. Their reading might be described as an act of internal reflection for the purpose of dematerialized self-cultivation. They do not attempt to physically sit at the feet of Jesus; instead, they conceptualize this as a dematerialized, internal, pious orientation, disconnected from their actual physical stance. In this light, the two cases we have presented may be analyzed as further evidence for the argument that Protestantism presents a type of Christian semiotic ideology that consistently (although never fully successfully) works toward abstraction and purification, seeking to be free from material confines (Keane 2007). 
However, if we leave aside the androgynous reader and instead pay attention to the fact that the readers in our two cases were embodiedgendered, classed, raced - a different analysis comes into view. We see that these women could not only strive for purification. They were prevented from doing so, and themselves did not desire to do so, because of their bodies, coded as female and thus inextricably tied, for example, to motherhood, domestic chores, and the home. Instead, they took a pluralistic approach to materiality, valuing a calm piety that transcended (while remaining in) the everyday hustle, right alongside valuing the physical piety of preparing food for others, in their place. Viewed from this angle, our cases show that the argument that Protestantism tends toward dematerialized purification is deeply gendered, reflecting an ideology of dominant masculinity and depicting an orientation to lived Protestantism that can only be taken up by certain groups. These groups need not pay attention to their own embodiment, and can thus afford to distance themselves from materiality in a way that the women we have studied could not.

If we extend this insight, we can see that the androgynous reader is not only a gap in theorizing about Christian reading but also a productive cultural device deeply enmeshed in the power hierarchies of Christian practice. The notion of an androgynous reader in fact bundles together the relationship of bodies and texts in one particular way, obscuring the fine, situated range of material and embodied engagements that can arise in acts of Christian reading. In doing so, it operates as an ideological shorthand that smooths over a complex set of issues surrounding reading as a cultural interaction, interpretive act, and set of embodied commitments, not separate from other forms of embodied worship in Protestant communities. These issues deserve further attention by scholars of Christianity in order to flesh out the stakes of reading as a practice of embodied engagement in Christian communities. Viewed through the lens of our reading communities, the particular Protestant semiotic ideology of purification could then be seen as a politicized, gendered proposition within Protestant communities that was not adopted by all but rather venerated as an example of correct practice, serving overall to maintain gendered, raced, and classed hierarchies of piety.

Our analysis, then, foregrounds the centrality of the relationship between reading and embodiment in these two Protestant communities. How can we conceptualize reading as an embodied and a textual practice? In answering this question, we have drawn inspiration from Shalini Shankar and Jillian Cavanaugh (2017), whose "language materiality" approach advocates paying attention to how each of the terms-language, materiality-helps us understand the other. In our cases, "putting language and materiality together at the center of analysis" (ibid.: 1) allows us to consider the integration between, on the one hand, concepts-being-worked-out by readers as they make and maintain a collective world, and on the other, the material realism 
of that world. In other words, as we examine readers reading in a reading community, we see a social world - a "human project"-being shaped through both epistemologies and materialities, in dynamic interaction (Keane and Silverstein 2017: 34). We are interested in how reading is interwoven with both human creativity and meaning-making, as well as the tangible effects of power on bodies.

In sum, we have argued through close analysis of our two cases that Christian reading is an embodied practice interweaving language and materiality in two distinct senses. Reading cannot be done outside of the embodied positions of the reader, a straightforward yet often overlooked part of the cultural work of reading. Identifying with a text happens in complex dialogue with readers' situated identities and embodied material circumstances. This means that reading as a Christian cultural activity is inextricably shaped by and contributes to intersectional identity formations, such as those of gender, race, class, and national identity, and the material conditions through which they always find expression. Reading is also embodied here in the sense that intertextual practices configure different styles of gendered action, which in turn can be embodied in various ways by readers. We see this in our analysis when women writers collapse Mary and Martha into an undifferentiated "we" to which readers identify, or when commentators compare their sweeping and cooking to Martha's work to host Jesus. Through reading, Lutheran mission-conscious women received some validation for considering several feminized tasks as a kind of Christian work or place in which women could be virtuous at the same time as they fulfilled their gendered responsibilities. Reading was a subtle, unfinished, embodied practice of working through these possibilities for reconciling the varying obligations and limits of Christian and intersectional identities.

\section{REFERENCES}

Abu-Lughod, Lila. 2015. Do Muslim Women Need Saving? Cambridge: Harvard University Press.

Amit, Vered, with Sally Anderson, Virginia Caputo, John Postill, Deborah ReedDanahay, and Gabriela Vargas-Cetina. 2015. Introduction. Thinking through Sociality: The Importance of Mid-Level Concepts. In Vered Amit, ed., Thinking through Sociality: An Anthropological Interrogation of Key Concepts. Oxford: Berghahn, 1-20.

Bandak, Andreas. 2015. Exemplary Series and Christian Typology: Modelling on Sainthood in Damascus. Journal of the Royal Anthropological Institute 21, S1: 47-63.

Bialecki, Jon and Eric Hoenes del Pinal. 2011. Introduction. Beyond Logos: Extensions of the Language Ideology Paradigm in the Study of Global Christainity(-ies). Anthropological Quarterly 84, 3: 575-93.

Bielo, James S., ed. 2009a. The Social Life of Scriptures: Cross-Cultural Perspectives on Biblicism. New Brunswick: Rutgers University Press.

Bielo, James S. 2009b. Words Upon the Word: An Ethnography of Evangelical Group Bible Study. New York: New York University Press. 
Bielo, James S. 2018. Ark Encounter: The Making of a Creationist Theme Park. New York: New York University Press.

Bowie, Fiona, Deborah Kirkwood, and Shirley Ardener, eds. 1993. Women and Missions: Past and Present: Anthropological and Historical Perceptions. Oxford: Berg.

Boyarin, Daniel. 1993. Placing Reading: Ancient Israel and Medieval Europe. In Jonathan Boyarin, ed., The Ethnography of Reading. Berkeley: University of California Press, 10-37.

Boyarin, Jonathan, ed. 1993a. The Ethnography of Reading. Berkeley: University of California Press.

Boyarin, Jonathan. 1993b. Voices around the Text: The Ethnography of Reading at Mesivta Tifereth Jerusalem. In Jonathan Boyarin, ed., The Ethnography of Reading. Berkeley: University of California Press, 212-37.

Brodkin Sacks, Karen. 1998. How Jews Became White Folks and What That Says about Race in America. New Brunswick: Rutgers University Press.

Cannell, Fenella. 2006. Reading as Gift and Writing as Theft. In Fenella Cannell, ed., The Anthropology of Christianity. Durham: Duke University Press, 134-62.

Casselberry, Judith. 2017. The Labor of Faith: Gender and Power in Black Apostolic Pentecostalism. Durham: Duke University Press.

Cerutti, Simona and Isabelle Grangaud. 2017. Sources and Contextualizations: Comparing Eighteenth-Century North African and Western European Institutions. Comparative Studies in Society and History 59, 1: 5-33.

Coleman, Simon. 1996. Words as Things: Language, Aesthetics and the Objectification of Protestant Evangelicalism. Journal of Material Culture 1, 1: 107-28.

Covington-Ward, Yolanda. 2016. Gesture and Power: Religion, Nationalism, and Everyday Performance in Congo. Durham: Duke University Press.

Crapanzano, Vincent. 2000. Serving the Word: Literalism in America from the Pulpit to the Bench. New York: New Press.

Csordas, Thomas. 2002. Body/Meaning/Healing. London: Palgrave Macmillan.

Dons, Henny. 1923. Kvindens Oppgave og Arbeide i Missionen. In Henny Dons and Johanne Hoel Olsen, Kvindens Missionsarbeide. Stavanger: Det Norske Missionsselskap, 3-10.

Dons, Henny. 1928. Bibelens Kvinner: Bibelstudier. Oslo: Lutherstiftelsens Forlag.

Engelke, Matthew. 2007. A Problem of Presence: Beyond Scripture in an African Church. Berkeley: University of California Press.

Engelke, Matthew. 2009. Reading and Time: Two Approaches to the Materiality of Scripture. Ethnos 74, 2: 151-74.

Engelke, Matthew. 2013. God's Agents: Biblical Publicity in Contemporary England. Berkeley: University of California Press.

Fish, Stanley E. 1980. Is There a Text in This Class? The Authority of Interpretive Communities. Cambridge: Harvard University Press.

Griffith, R. Marie. 2000. God's Daughters: Evangelical Women and the Power of Submission. Berkeley: University of California Press.

Griffith, R. Marie. 2004. Born Again Bodies: Flesh and Spirit in American Christianity. Berkeley: University of California Press.

Harding, Susan. 2000. The Book of Jerry Falwell: Fundamentalist Language and Politics. Princeton: Princeton University Press.

Haynes, Naomi. 2020. The Expansive Present: A New Model of Christian Time. Current Anthropology 61, 1: 57-76.

Hill, Patricia. 1985. The World Their Household: The American Woman's Foreign Mission Movement and Cultural Transformation, 1870-1920. Ann Arbor: University of Michigan Press. 
Huber, Mary Taylor and Nancy Lutkehaus, eds. 1999. Gendered Missions: Women and Men in Missionary Discourse and Practice. Ann Arbor: University of Michigan Press.

Irvine, R.D.G. 2010. How to Read: Lectio Divina in an English Benedictine Monastery. Culture and Religion 11, 4: 395-411.

Keane, Webb. 2007. Christian Moderns: Freedom and Fetish in the Mission Encounter. Berkeley: University of California Press.

Keane, Webb and Michael Silverstein. 2017. Curated Conversation: "Materiality: It's the Stuff!" In Jillian R. Cavanaugh and Shalini Shankar, eds., Language and Materiality: Ethnographic and Theoretical Explorations. Cambridge: Cambridge University Press, 29-40.

Keller, Eva. 2005. The Road to Clarity: Seventh-Day Adventism in Madagascar. London: Palgrave Macmillan.

Kirsch, Thomas G. 2008. Spirits and Letters: Reading, Writing and Charisma in African Christianity. Oxford: Berghahn Books.

Klassen, Pamela. 2011. Spirits of Protestantism: Medicine, Healing and Liberal Christianity. Berkeley: University of California Press.

Lagerquist, L. DeAne. 1987. From Our Mothers' Arms: A History of Women in the American Lutheran Church. Minneapolis: Augsburg Publishing House.

Lester, Rebecca. 2005. Jesus in Our Wombs: Embodying Modernity in a Mexican Convent. Berkeley: University of California Press.

Long, Elizabeth. 1993. Textual Interpretation as Collective Action. In Jonathan Boyarin, ed., The Ethnography of Reading. Berkeley: University of California Press, 180-211.

Long, Kathryn T. 2003. In the Modern World, but Not of It. The 'Auca Martyrs,' Evangelicalism, and Postwar American Culture. In Daniel H. Bays and Grant Wacker, eds., The Foreign Missionary Enterprise at Home: Explorations in North American Cultural History. Tuscaloosa: University of Alabama Press, 223-36.

McDannell, Colleen. 1995. Material Christianity: Religion and Popular Culture in America. New Haven: Yale University Press.

Meyer, Birgit. 2006. Religious Sensations: Why Media, Aesthetics, and Power Matter in the Study of Contemporary Religion. Amsterdam: Faculteit der Sociale Wetenschappen, Vrije Universiteit.

Meyer, Birgit, David Morgan, Crispin Paine, and S. Brent Plate. 2010. The Origin and Mission of Material Religion. Religion 40, 3: 207-11.

Mikaelsson, Lisbeth. 2002. 'Kvinne, Ta Ansvar og Ledelse i Dine Egne Hender': Historien om Henny Dons. Norsk Tidsskrift for Misjon 56, 2: 107-37.

Nelson, E. Clifford. 1980. The Lutherans in North America. Rev. ed. Philadelphia: Fortress Press.

Nome, John. 1943. Det Norske Misjonsselskaps Historie i Norsk Kirkeliv: Fra Syttiårene til Nåtiden. Vol. 2 of Det Norske Misjonsselskaps Historie i Hundre Ar. Stavanger: Dreyer.

Ong, Walter J. 2012[1982]. Orality and Literacy. New York: Routledge.

Reed, Adam. 2018. Literature and Reading. Annual Review of Anthropology 47, 33-45.

Rosen, Matthew. 2015. Ethnographies of Reading: Beyond Literacy and Books. Anthropological Quarterly 88, 4: 1059-83.

Shankar, Shalini and Jillian R. Cavanaugh. 2017. Toward a Theory of Language Materiality: An Introduction. In Jillian R. Cavanaugh and Shalini Shankar, eds., Language and Materiality: Ethnographic and Theoretical Explorations. Cambridge: Cambridge University Press, 1-28.

Steedman, Carolyn. 2009. Literacy, Reading, and Concepts of the Self. In David R. Olson and Nancy Torrance, eds., The Cambridge Handbook of Literacy. Cambridge: Cambridge University Press, 221-41. 
Stoler, Ann L. 2008. Along the Archival Grain: Epistemic Anxieties and Colonial Common Sense. Princeton: Princeton University Press.

Strhan, Anna. 2015. Aliens and Strangers? The Struggle for Coherence in the Everyday Lives of Evangelicals. Oxford: Oxford University Press.

Yohn, Susan M. 2002. "Let Christian Women Set Their Own Gifts": The "Business" of Protestant Women's Organizations. In Margaret Lamberts Bendroth and Virginia Lieson Brereton, eds., Women and Twentieth-Century Protestantism. Urbana: University of Illinois Press, 213-35. 
Abstract: What do Christians do when they read? How can Christian reading be understood anthropologically? Anthropologists of Christianity have offered many ethnographic descriptions of the interplay among people, words, and material objects across Christian groups, but descriptions of Christian reading have often posited an androgynous reader. In response to this we begin from the observation that while reading cannot be done without words, it also cannot be done without a body. We propose that an analytic approach of placing language and materiality (including bodies) together will help clarify that reading texts is an embodied practice, while not undermining the importance of working with words. We draw inspiration from the recent interest in bringing linguistic anthropology and materiality studies together into the same analytic frame of "language materiality." We explore a languagemateriality approach to reading by comparing how the biblical story of Mary and Martha was read by Protestant women in two historical situations: 1920s Norway and the 1950s United States. We argue that in these cases the readers' gendered, raced, and classed bodies were central to the activity of reading texts, including their bodies' material engagements with the world, such as carrying out women's work. We suggest that paying attention to embodied reading - that is, readers' social entanglements with both language and materiality-yields a fuller analysis of what reading is in particular historical situations, and ultimately questions the notion of a singular Protestant semiotic ideology that works consistently toward purification.

Key words: Bible, Christianity, embodiment, gender, language, materiality, reading, texts, work 